\title{
Expression of Trophic Peptides and Their Receptors in Chromaffin Cells and Pheochromocytoma
}

\author{
Erwan Thouënnon • Alice Pierre - Laurent Yon · Youssef Anouar
}

\begin{abstract}
Pheochromocytomas are catecholamine-producing tumors arising from chromaffin cells of the adrenal medulla or extra-adrenal location. Along with catecholamines, tumoral cells produce and secrete elevated quantities of trophic peptides which are normally released in a regulated manner by the normal adrenal medulla. Among these peptides, the amounts of pituitary adenylate cyclaseactivating polypeptide (PACAP), adrenomedullin (AM), and neuropeptide Y (NPY) are particularly high. These peptides can exert endocrine, paracrine or autocrine effects in numerous cell types. In particular, they have been shown to be involved in cell proliferation and survival, catecholamine production and secretion, and angiogenesis. Some of these processes are exacerbated in pheochromocytomas, raising the possibility of the involvement of trophic peptides. Here, we review the expression levels of NPY, PACAP, and AM and theirs receptors in chromaffin cells and pheochromocytomas, and address their possible implication in the adrenal medulla tumorigenesis and malignant development of pheochromocytomas.
\end{abstract}

Keywords Chromaffin cells · Pheochromocytomas · Trophic peptides · Tumorigenesis · Malignancy

E. Thouënnon · A. Pierre $\cdot$ L. Yon · Y. Anouar $(\bowtie)$

INSERM, U982, DC2N, IFRMP23, University of Rouen,

Mont-Saint-Aignan, France

e-mail: youssef.anouar@univ-rouen.fr

Present Address:

E. Thouënnon

Section on Cellular Neurobiology, Laboratory of Developmental

Neurobiology, Eunice Kennedy Shriver NICHD, NIH,

Bethesda, MD 20892, USA

\section{Introduction}

Pheochromocytomas are neuroendocrine tumors arising from chromaffin cells of the adrenal medulla or extraadrenal locations. These tumors exhibit impaired control of peptide and hormone biosynthesis and secretion, resulting in an exacerbated production of these factors (Thouënnon et al. 2007). In particular, the main clinical symptoms indicating the occurrence of a pheochromocytoma are provoked by excessive release of catecholamines, dopamine, norepinephrine, and epinephrine, into the bloodstream. Along with catecholamines, pheochromocytomas produce and secrete numerous peptides. These peptides are also secreted along with catecholamines in physiological conditions, in order to participate in homeostatic regulations. Thus, peptides, such as neuropeptide Y (NPY) and adrenomedullin (AM), play an important role in the stress response (Edvinsson et al. 1983; Shimosawa and Fujita 2005). Other peptides, such as pituitary adenylate cyclaseactivating polypeptide (PACAP) can act as neurotransmitters in chromaffin cells (Lamouche and Yamaguchi 2003; Payet et al. 2003). In addition, these peptides can also act locally as trophic factors. In particular, NPY, AM, and PACAP have been shown to be involved in hormone production and secretion, as well as proliferation, survival or differentiation of numerous cell types (Shimosawa and Fujita 2005; Dumont and Quirion 2006; Vaudry et al. 2009). In pathophysiological conditions, alteration of NPY, AM, and PACAP expression, production and regulated secretion may lead to potential paracrine, autocrine or endocrine defects. Although these peptides have been extensively studied in different tumors, such as brain tumors, breast carcinomas, prostate cancer, and neuroblastomas, their roles in pheochromocytomas, where they are present in very high quantities, remain poorly understood 
(Garcia-Fernandez et al. 2004; Moretti et al. 2006; Nakamura et al. 2006; Ruscica et al. 2007).

In this review, we focused on the expression of NPY, PACAP, and AM and their receptors in adrenal medulla, and benign and malignant pheochromocytomas. We also described their effects on chromaffin cells and pheochromocytes, and how they could possibly be involved in adrenal gland tumorigenesis and pheochromocytoma metastasis.

\section{NPY}

NPY is a 36-amino acid peptide originally isolated from porcine brain (Tatemoto et al. 1982). This neuropeptide acts as a co-transmitter, a neuromodulator and a neurohormone, and plays an important role in numerous physiological processes such as food intake, hormone secretion or regulation of the immune system (Zukowska et al. 2003). NPY is also considered as a growth factor for several cell types such as neuronal cells or smooth muscle cells (Hansel et al. 2001; Pons et al. 2003). NPY is an angiogenic factor able to stimulate the proliferation and migration of endothelial cells, the formation of capillary tubes and the revascularization of ischemic tissues (Lee et al. 2003). Moreover, NPY has already been shown to be involved in cell proliferation, angiogenesis, invasion, and metastasization of endocrine-related tumors (Ruscica et al. 2007).

In human and other mammalian species, high concentrations of NPY have been found in the brain and the sympathetic nerve system, including adrenal medulla (Allen et al. 1983). In the latter tissue, NPY concentrations are higher than those measured in the adrenal cortex in all studied species (Allen et al. 1983; de Quidt and Emson 1986)

NPY is co-secreted with norepinephrine and exerts a strong vasoconstrictor effect on cardiovascular system vessels, making this peptide an actor of the stress response (Edvinsson et al. 1983).

So far, six receptors, Y1, Y2, Y3, Y4, Y5, and y6, have been described as NPY receptors. In human, the $\mathrm{y} 6$ receptor is a pseudogene, coding for a non-functional truncated protein (Rose et al. 1997). Moreover, there is some confusion regarding the human $\mathrm{Y} 3$ receptor, frequently described as a putative and uncharacterized receptor (Fetissov et al. 2004; Larhammar and Salaneck 2004). However, a recent update of the National Center for Biotechnology Information (NCBI) website clarified the situation: the Y3 receptor does not seem to bind human NPY but exhibits a strong affinity to stromal cell-derived factor 1 (SDF1) chemokine. The Y3 receptor was thus renamed CXC chemokine receptor 4 (CXCR4), in accordance with the chemokines receptor nomenclature (Bleul et al. 1996).

In the human adrenal medulla, the receptors Y1, Y2, Y4, and Y5 are expressed and functional, indicating that NPY exerts autocrine effects in this tissue (Cavadas et al. 2001; Korner et al. 2004; Spinazzi et al. 2005). The expression of the CXCR4 in this tissue has not been shown.

Few studies have reported on the effect of NPY on chromaffin cells. In human and murine chromaffin cells in primary culture, NPY is able to stimulate catecholamine secretion (Cavadas et al. 2001, 2006). It has also been shown that NPY treatment of rat or bovine chromaffin cells in primary culture is able to inhibit cholinergic agonist-induced catecholamine secretion (Hexum and Russett 1989; Shimoda et al. 1993). Strikingly, the opposite effect has been observed when the adrenal gland was perfused (Hexum and Russett 1989). In addition to its role in the regulation of catecholamine secretion, NPY is also able to act upstream, at the level of catecholamine biosynthesis, as shown by tyrosine hydroxylase $(\mathrm{TH})$ overexpression observed in rat adrenal medulla in which NPY has been injected (Hong et al. 1995). Moreover, a simultaneous treatment by ATP and NPY enhanced TH serine 31-phosphorylation, which would stabilize this enzyme (Luke and Hexum 2008).

In human pheochromocytomas, the existence of NPY-producing cells and high NPY concentrations have been reported (deS Senanayake et al. 1995). These high intra-tumoral quantities of NPY can be explained by a strong expression of the gene, associated with an efficient maturation of the precursor (O'Hare and Schwartz 1989; Thouënnon et al. 2010). In pheochromocytoma patients, plasma NPY concentration is often elevated, particularly when the tumor is malignant. However, the percentage of patients with elevated plasma NPY levels is similar for benign and malignant tumors (Grouzmann et al. 1990). In tumoral tissue, NPY expression has been shown to be lower in malignant compared to benign pheochromocytomas (Thouënnon et al. 2010), although the differences were not found statistically significant in another study who also compared the two tumor subtypes (deS Senanayake et al. 1995; Thouënnon et al. 2010). In a subtype of hereditary pheochromocytomas associated with mutation of the von Hippel-Lindau gene, it has been shown that the expression level of NPY was significantly lower than in other hereditary and sporadic pheochromocytomas (Cleary et al. 2007). Together, these observations suggest that NPY levels are high but variable in pheochromocytoma and that this peptide could be differentially produced by different tumor subtypes.

We showed the expression of all NPY receptors in almost all studied benign and malignant pheochromocytomas, with no differences between benign and malignant tumors. Despite the fact that this expression was very 
weak, we cannot exclude the possibility of an autocrine effect of NPY in these tumors, given the elevated amounts of the peptide produced by pheochromocytomas (Thouënnon et al. 2010).

Altogether, these data suggest that NPY could act in an autocrine manner on catecholamine production and secretion and therefore participates in pathophysiological mechanisms involved in these tumors. Interestingly, although NPY does not seem to be involved in the proliferation or apoptosis of PC12 cells, arguing against a role of this peptide in chromaffin cell transformation, it has nevertheless been shown that NPY could participate in tumoral growth by stimulating neoangiogenesis (Kitlinska et al. 2005; Kitlinska 2007).

\section{PACAP}

PACAP is an ubiquitous neuropeptide of 27 or 38 -amino acid involved in numerous physiological functions (Vaudry et al. 2009). In rat, several studies showed the expression of the PACAP gene and the occurrence of peptide immunoreactivity in fibers innerving the adrenal medulla (Nielsen et al. 1998). Other studies showed the presence of PACAP in chromaffin cells of several mammalian species and in human fetal chromaffin cells (Breault et al. 2000).

Numerous in vitro and in vivo studies showed that PACAP acts as a neurotransmitter in order to regulate catecholamine secretion by chromaffin cells in physiological and pathophysiological conditions (Lamouche and Yamaguchi 2003; Payet et al. 2003; Isobe et al. 2004). These effects of PACAP on catecholamine secretion are associated with increased expression of $\mathrm{TH}$, dopamine $\beta$-hydroxylase, and phenylethanolamine $N$-methyltransferase (PNMT) genes, concomitantly with increased activity of these enzymes (Tonshoff et al. 1997; McKenzie and Marley 2002). However, immunolabeling of $\mathrm{TH}$ and PNMT enzymes is similar in PACAP knock-out and wildtype mice, suggesting that the peptide does not exert an important role in the maintenance of the catecholaminergic phenotype of chromaffin cells and in the development of the adrenal medulla (Hamelink et al. 2002).

PACAP also stimulates the expression and secretion of several neuropeptides such as VIP, galanin, the brain natriuretic peptide or enkephalins (Babinski et al. 1996; Lee et al. 1999; Guillemot et al. 2006a). Moreover, it has been shown that treatment of bovine chromaffin cells by PACAP leads to increased expression and secretion of secretogranin II and its derived peptides secretoneurin and EM66 (Guillemot et al. 2006b).

In the rat pheochromocytoma PC12 cell line, PACAP is able to stimulate catecholamine secretion, to inhibit cell proliferation and to induce differentiation toward a sympathetic phenotype through molecular pathways similar to those activated by nerve growth factor (Grumolato et al. 2003). In these cells, PACAP also exerts protective effects against ceramide, $\beta$-amyloid or hydrogen peroxide-induced stress (Ghzili et al. 2008). In addition, the neuropeptide also stimulates gene transcription of $\mathrm{TH}$ and PNMT enzymes, the vesicular monoamine transporter 1 , the vesicular acetylcholine transporter and chromogranin A and $\mathrm{B}$, but inhibits the expression of secretogranin II (Grumolato et al. 2003).

In human intra- and extra-adrenal pheochromocytomas, a PACAP-like immunoreactivity has been found in all studied tumors (Takahashi et al. 1993; Fahrenkrug et al. 1995). In half of pheochromocytoma cases, this immunoreactivity was high as compared to cortical or adrenal medulla (Takahashi et al. 1993). Isobe et al. (2003) showed that PACAP was expressed in 24 out of 30 studied tumors. In intra-adrenal pheochromocytomas, this expression was strongly correlated to those of TH and PNMT genes and to intra-tumoral epinephrine concentrations, suggesting that PACAP may regulate the expression of the genes encoding catecholamine-synthesizing enzymes. In a set of 25 benign and malignant pheochromocytomas and paragangliomas, we also showed the wide expression of PACAP, which was detected in 24 of these tumors. However, we did not observe significantly different expression levels between benign and malignant pheochromocytomas (Thouënnon et al. 2010). In this pheochromocytoma cohort, we also showed that the levels of PACAP and NPY were correlated and that PACAP was able to increase the expression of NPY in PC12 cells (Fig. 1; Thouënnon et al., unpublished data). This observation suggests that PACAP could exert direct trophic effects but could also exert indirect effects through stimulation of the expression of other trophic peptides.

PACAP exerts its effects by binding to VIP/PACAP receptors (VPAC1-R and VPAC2-R) and the PACAPpreferring receptor (PAC1-R). In chromaffin cells, PAC1-R is the predominant receptor but VPAC2- $\mathrm{R}$ is also present (Harmar et al. 2004). PAC1-R has also been detected in human fetal chromaffin cells (Yon et al. 1998). PAC1-R is involved in the effects of PACAP on peptide and catecholamine biosynthesis in the adrenal medulla (Ghzili et al. 2008).

We showed the expression of the PAC1 receptor in all studied pheochromocytomas whereas that of VPAC1-R and VPAC2-R mRNAs was only detected in half of them. Moreover, mean PAC1-R expression levels were about 20 -fold higher than those of VPAC1-R and VPAC2-R. This high expression of PAC1-R is in line with the data reported in a previous study showing that PAC1-R mRNA is found in $83 \%$ of tumors among a set of 43 pheochromocytomas 

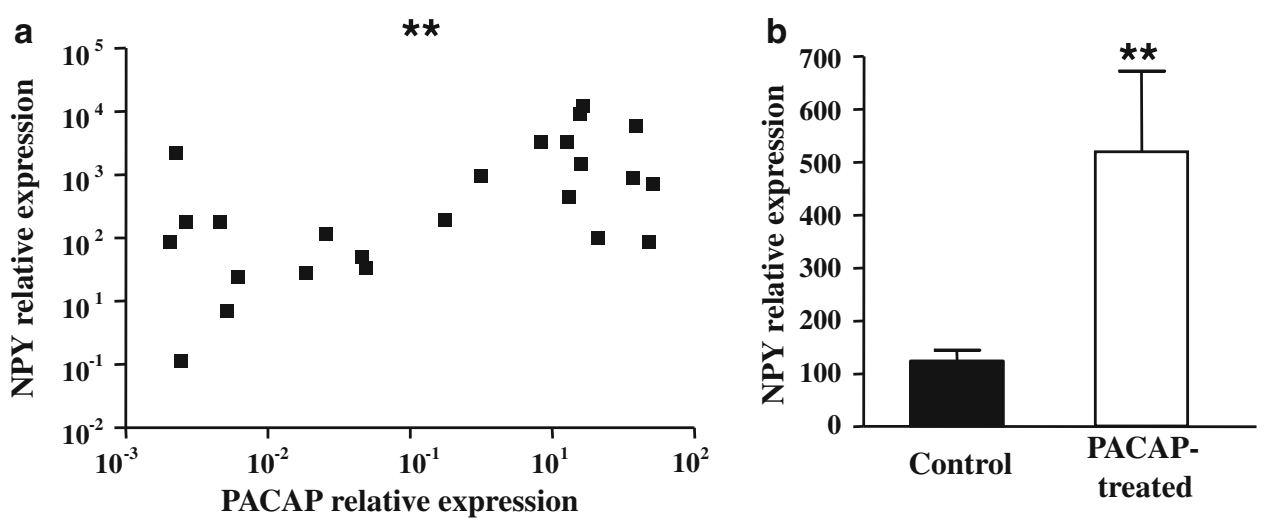

Fig. 1 Correlation between expression levels of PACAP and NPY in a set of 25 pheochromocytomas (a) and effect of treatment of PC12 cells with PACAP on NPY expression (b). a This study performed by real-time PCR shows that PACAP and NPY expression were

and paragangliomas (Reubi et al. 2000). Another study showed the expression of PAC1-R in only $63 \%$ of the pheochromocytomas and paragangliomas analyzed, but this lower rate could be explained by the use of a less sensitive technique (Isobe et al. 2003). These results indicate that PAC1-R is the main receptor potentially mediating autocrine/paracrine effects of PACAP in pheochromocytomas.

Interestingly, PAC1-R is involved in the proliferation of several tumoral cells and is the receptor mediating the neuroprotective effects of PACAP (Dejda et al. 2008).

Altogether, these data suggest that PACAP, through its PAC1 receptor, could play an important role into the pathophysiology of pheochromocytomas. PACAP may exert trophic and anti-apoptotic effects on tumoral cells and, may increase the biosynthesis and secretion of catecholamines and other trophic peptides in these tumors.

\section{AM}

$\mathrm{AM}$ is a 52-amino acid peptide originally isolated from a human pheochromocytoma, which exhibits a high sequence homology with calcitonin gene-related peptide (CGRP) (Kitamura et al. 1993). AM is also present at high concentrations in the adrenal medulla, is secreted in the bloodstream and exerts hypotensive effects, acting on vasodilatation and increasing diuresis and sodium secretion in urine (Shimosawa and Fujita 2005). AM also possesses a proliferative and anti-apoptotic actions on some cell types (Malendowicz et al. 2003; Uzan et al. 2008).

In primary cultures of bovine chromaffin cells, it has been shown that AM is stored in dense core vesicles and released along with catecholamines upon stimulation (Kobayashi et al. 2001a). Moreover, there is an increase in $\mathrm{AM}$ and concomitant catecholamine secretion when significantly correlated in human pheochromocytomas. $* * P<0.01$; $r=0.5631$. b A 48 -h treatment of PC12 by PACAP significantly increased NPY expression. $* * P<0.01$

these cells are under hypoxia conditions (Kobayashi et al. 2003).

So far, three AM receptors, also exhibiting affinity for the CGRP, have been found: the adrenomedullin receptor (ADMR), the receptor dog cDNA 1 (RDC1), and the calcitonin receptor-like receptor (CRLR) linked to the receptor activity-modifying proteins 1,2 or 3 (RAMP1-3). CRLR association with RAMP2 or 3 allows formation of a receptor displaying higher affinity for AM than for CGRP, while association with RAMP1 results in the opposite effect (Kobayashi et al. 2001b). In rat adrenal medulla, CRLR and ADMR receptors are exclusively detected in noradrenergic cells, while AM is mainly detected in adrenergic cells, suggesting a paracrine role for this peptide (Renshaw et al. 2000).

Treatment of rat or human chromaffin cells with AM provokes catecholamine secretion (Mazzocchi et al. 1999). However, this effect has not been observed in primary cultures of bovine chromaffin cells (Kobayashi et al. 2001b). In addition, in dog, injection of AM in the adrenal gland does not influence the secretion of catecholamines, even if a stimulation of the splanchnic nerve or an injection of acetylcholine is performed at the same time (Masada et al. 1999). These results indicate that AM could have a role in the exocytosis of catecholamines from chromaffin cells in some species but not in others.

In human pheochromocytomas, we were able to detect AM expression in all of the 25 tumors analyzed, without differences between benign and malignant tumors. We observed that AM exerts anti-apoptotic effects on human pheochromocytomas in primary culture and on PC12 cells (Thouënnon et al. 2010). Moreover, although no data is available for pheochromocytomas, numerous studies showed the overexpression of AM by several cell lines during hypoxia conditions. This overexpression is associated 
with a role of AM in angiogenesis, including tumoral angiogenesis (Zudaire et al. 2003).

We also detected very low ADMR and CRLR mRNA levels in all tumors analyzed. Moreover, expression of RAMP2 and 3 was also very weak, exhibiting 2- to 12-fold lower levels than RAMP1 expression levels, which suggests that in pheochromocytomas CRLR/RAMP association is more likely forming a receptor with affinity towards CGRP. On the contrary, RDC1 expression in these tumors was very high, showing 20 - to 30 -fold higher levels than those of ADMR and CRLR, indicating that RDC1 is likely the receptor mediating AM effects in pheochromocytomas (Thouënnon et al. 2010). Moreover, RDC1 is overexpressed in malignant pheochromocytomas, and down-regulation of its expression in $\mathrm{PC} 12$ cells reduced the number of cells (Thouënnon et al. 2010). Interestingly, RDC1 has already been shown to be overexpressed in several cancers and to be associated with the malignant behavior of tumors, i.e., invasiveness, survival, proliferation, and neoangiogenesis (Miao et al. 2007; Wang et al. 2008). In addition, Autelitano et al. have shown that the effects of AM on vascular smooth muscle cells and cardiac myocytes may involve RDC1 (Autelitano 1998; Autelitano and Tang 1999). Although no study has shown an association between RDC1 and angiogenesis in pheochromocytomas, it is interesting to note that expression levels of this receptor and those of the vascular endothelial growth factor are strongly and significantly correlated in a set of 13 pheochromocytomas (Fig. 2; Thouënnon et al., unpublished data).

Altogether, these data strongly suggest that AM and its $\mathrm{RDC} 1$ receptor could participate in the tumorigenesis of chromaffin cells, supporting neoangiogenesis or allowing tumoral cell survival. Moreover, overexpression of RDC1

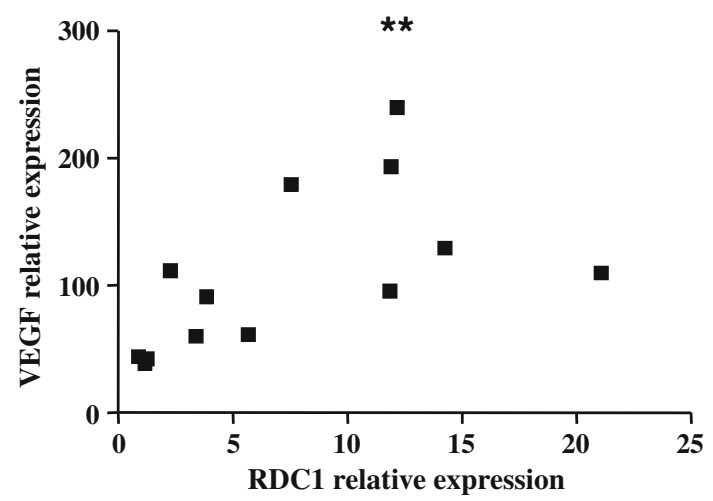

Fig. 2 Correlation between the expression levels of RDC1 and VEGF in a set of 13 pheochromocytomas. This study performed by real-time PCR showed that DC1 and VEGF expression were strongly and significantly correlated in human pheochromocytomas. ** $P<0.01 ; r=0.7637$ in malignant pheochromocytomas suggests a role for this receptor into tumor metastasis.

\section{Conclusion}

There is growing evidence that several peptides may play an important role in the pathophysiology of pheochromocytoma. Peptides such as NPY, PACAP, and AM may act on catecholamine release but also on cell survival and growth, representing thus with their receptors valuable targets in order to design new therapeutic tools for the management of these neuroendocrine tumors.

Acknowledgments This work was financially supported by the Association pour la Recherche sur le Cancer, Ligue Nationale de Recherche Contre le Cancer, The COMETE Network (PHRC no. 06179).

\section{References}

Allen JM, Adrian TE, Polak JM, Bloom SR (1983) Neuropeptide Y (NPY) in the adrenal gland. J Auton Nerv Syst 9:559-563

Autelitano DJ (1998) Cardiac expression of genes encoding putative adrenomedullin/calcitonin gene-related peptide receptors. Biochem Biophys Res Commun 250:689-693

Autelitano DJ, Tang F (1999) Co-expression of prepro-adrenomedullin with a putative adrenomedullin receptor gene in vascular smooth muscle. Clin Sci 96:493-498

Babinski K, Bodart V, Roy M, De Lean A, Ong H (1996) Pituitary adenylate-cyclase activating polypeptide (PACAP) evokes longlasting secretion and de novo biosynthesis of bovine adrenal medullary neuropeptides. Neuropeptides 30:572-582

Bleul CC, Farzan M, Choe H, Parolin C, Clark-Lewis I, Sodroski J, Springer TA (1996) The lymphocyte chemoattractant SDF-1 is a ligand for LESTR/fusin and blocks HIV-1 entry. Nature 382:829-833

Breault L, Yon L, Montero M, Chouinard L, Contesse V, Delarue C, Fournier A, Lehoux JG, Vaudry H, Gallo-Payet N (2000) Occurrence and effect of PACAP in the human fetal adrenal gland. Ann N Y Acad Sci 921:429-433

Cavadas C, Silva AP, Mosimann F, Cotrim MD, Ribeiro CA, Brunner HR, Grouzmann E (2001) NPY regulates catecholamine secretion from human adrenal chromaffin cells. J Clin Endocrinol Metab 86:5956-5963

Cavadas C, Cefai D, Rosmaninho-Salgado J, Vieira-Coelho MA, Moura E, Busso N, Pedrazzini T, Grand D, Rotman S, Waeber B, Aubert JF, Grouzmann E (2006) Deletion of the neuropeptide Y (NPY) Y1 receptor gene reveals a regulatory role of NPY on catecholamine synthesis and secretion. Proc Natl Acad Sci USA 103:10497-10502

Cleary S, Phillips JK, Huynh TT, Pacak K, Elkahloun AG, Barb J, Worrell RA, Goldstein DS, Eisenhofer G (2007) Neuropeptide Y expression in phaeochromocytomas: relative absence in tumours from patients with von Hippel-Lindau syndrome. J Endocrinol 193:225-233

de Quidt ME, Emson PC (1986) Neuropeptide Y in the adrenal gland: characterization, distribution and drug effects. Neuroscience 19:1011-1022

Dejda A, Jolivel V, Bourgault S, Seaborn T, Fournier A, Vaudry H, Vaudry D (2008) Inhibitory effect of PACAP on caspase activity 
in neuronal apoptosis: a better understanding towards therapeutic applications in neurodegenerative diseases. $\mathrm{J}$ Mol Neurosci 36:26-37

deS Senanayake P, Denker J, Bravo EL, Graham RM (1995) Production, characterization, and expression of neuropeptide $\mathrm{Y}$ by human pheochromocytoma. J Clin Invest 96:2503-2509

Dumont Y, Quirion R (2006) An overview of neuropeptide Y: pharmacology to molecular biology and receptor localization. EXS 95:7-33

Edvinsson L, Emson P, McCulloch J, Tatemoto K, Uddman R (1983) Neuropeptide Y: cerebrovascular innervation and vasomotor effects in the cat. Neurosci Lett 43:79-84

Fahrenkrug J, Buhl T, Hannibal J (1995) PreproPACAP-derived peptides occur in VIP-producing tumours and co-exist with VIP. Regul Pept 58:89-98

Fetissov SO, Kopp J, Hokfelt T (2004) Distribution of NPY receptors in the hypothalamus. Neuropeptides 38:175-188

Garcia-Fernandez MO, Bodega G, Ruiz-Villaespesa A, Cortes J, Prieto JC, Carmena MJ (2004) PACAP expression and distribution in human breast cancer and healthy tissue. Cancer Lett 205:189-195

Ghzili H, Grumolato L, Thouënnon E, Tanguy Y, Turquier V, Vaudry $\mathrm{H}$, Anouar Y (2008) Role of PACAP in the physiology and pathology of the sympathoadrenal system. Front Neuroendocrinol 29:128-141

Grouzmann E, Gicquel C, Plouin PF, Schlumberger M, Comoy E, Bohuon C (1990) Neuropeptide Y and neuron-specific enolase levels in benign and malignant pheochromocytomas. Cancer 66:1833-1835

Grumolato L, Louiset E, Alexandre D, Ait-Ali D, Turquier V, Fournier A, Fasolo A, Vaudry H, Anouar Y (2003) PACAP and NGF regulate common and distinct traits of the sympathoadrenal lineage: effects on electrical properties, gene markers and transcription factors in differentiating PC12 cells. Eur J Neurosci $17: 71-82$

Guillemot J, Ait-Ali D, Turquier V, Montero-Hadjadje M, Fournier A, Vaudry H, Anouar Y, Yon L (2006a) Involvement of multiple signaling pathways in PACAP-induced EM66 secretion from chromaffin cells. Regul Pept 137:79-88

Guillemot J, Ait-Ali D, Turquier V, Montero-Hadjadje M, Fournier A, Vaudry H, Anouar Y, Yon L (2006b) PACAP stimulates the release of the secretogranin II-derived peptide EM66 from chromaffin cells. Ann N Y Acad Sci 1070:309-312

Hamelink C, Tjurmina O, Damadzic R, Young WS, Weihe E, Lee HW, Eiden LE (2002) Pituitary adenylate cyclase-activating polypeptide is a sympathoadrenal neurotransmitter involved in catecholamine regulation and glucohomeostasis. Proc Natl Acad Sci USA 99:461-466

Hansel DE, Eipper BA, Ronnett GV (2001) Neuropeptide Y functions as a neuroproliferative factor. Nature 410:940-944

Harmar AJ, Sheward WJ, Morrison CF, Waser B, Gugger M, Reubi JC (2004) Distribution of the VPAC2 receptor in peripheral tissues of the mouse. Endocrinology 145:1203-1210

Hexum TD, Russett LR (1989) Stimulation of cholinergic receptor mediated secretion from the bovine adrenal medulla by neuropeptide Y. Neuropeptides 13:35-41

Hong M, Li S, Fournier A, St-Pierre S, Pelletier G (1995) Role of neuropeptide $\mathrm{Y}$ in the regulation of tyrosine hydroxylase gene expression in rat adrenal glands. Neuroendocrinology 61:85-88

Isobe K, Tatsuno I, Yashiro T, Nanmoku T, Takekoshi K, Kawakami Y, Nakai T (2003) Expression of mRNA for PACAP and its receptors in intra- and extra-adrenal human pheochromocytomas and their relationship to catecholamine synthesis. Regul Pept 110:213-217

Isobe K, Kaneko M, Kaneko S, Nissato S, Nanmoku T, Takekoshi K, Okuda Y, Kawakami Y (2004) Expression of mRNAs for
PACAP and its receptor in human neuroblastomas and their relationship to catecholamine synthesis. Regul Pept 123:29-32

Kitamura K, Kangawa K, Kawamoto M, Ichiki Y, Nakamura S, Matsuo H, Eto T (1993) Adrenomedullin: a novel hypotensive peptide isolated from human pheochromocytoma. Biochem Biophys Res Commun 192:553-560

Kitlinska J (2007) Neuropeptide Y in neural crest-derived tumors: effect on growth and vascularization. Cancer Lett 245:293-302

Kitlinska J, Abe K, Kuo L, Pons J, Yu M, Li L, Tilan J, Everhart L, Lee EW, Zukowska Z, Toretsky JA (2005) Differential effects of neuropeptide $\mathrm{Y}$ on the growth and vascularization of neural crest-derived tumors. Cancer Res 65:1719-1728

Kobayashi H, Yamamoto R, Kitamura K, Kuwasako K, Minami S, Yanagita T, Shiraishi S, Yokoo H, Eto T, Wada A (2001a) Selective inhibition of nicotinic cholinergic receptors by proadrenomedullin $\mathrm{N}$-terminal 12 peptide in bovine adrenal chromaffin cells. Brain Res Mol Brain Res 87:175-183

Kobayashi H, Yanagita T, Yokoo H, Wada A (2001b) Adrenomedullin and proadrenomedullin $\mathrm{N}$-terminal 20 peptide (PAMP) in adrenal chromaffin cells. Peptides 22:1895-1901

Kobayashi H, Yanagita T, Yokoo H, Wada A (2003) Pathophysiological function of adrenomedullin and proadrenomedullin N-terminal peptides in adrenal chromaffin cells. Hypertens Res 26 Suppl:S71-S78

Korner M, Waser B, Reubi JC (2004) High expression of neuropeptide y receptors in tumors of the human adrenal gland and extraadrenal paraganglia. Clin Cancer Res 10:8426-8433

Lamouche S, Yamaguchi N (2003) PACAP release from the canine adrenal gland in vivo: its functional role in severe hypotension. Am J Physiol Regul Integr Comp Physiol 284:R588-R597

Larhammar D, Salaneck E (2004) Molecular evolution of NPY receptor subtypes. Neuropeptides 38:141-151

Lee HW, Hahm SH, Hsu CM, Eiden LE (1999) Pituitary adenylate cyclase-activating polypeptide regulation of vasoactive intestinal polypeptide transcription requires $\mathrm{Ca}^{2+}$ influx and activation of the serine/threonine phosphatase calcineurin. J Neurochem 73:1769-1772

Lee EW, Michalkiewicz M, Kitlinska J, Kalezic I, Switalska H, Yoo P, Sangkharat A, Ji H, Li L, Michalkiewicz T, Ljubisavljevic M, Johansson H, Grant DS, Zukowska Z (2003) Neuropeptide $\mathrm{Y}$ induces ischemic angiogenesis and restores function of ischemic skeletal muscles. J Clin Invest 111:1853-1862

Luke TM, Hexum TD (2008) Tyrosine hydroxylase phosphorylation increases in response to ATP and neuropeptide Y co-stimulation of ERK2 phosphorylation. Pharmacol Res 58:52-57

Malendowicz LK, Conconi MT, Parnigotto PP, Nussdorfer GG (2003) Endogenous adrenomedullin system regulates the growth of rat adrenocortical cells cultured in vitro. Regul Pept 112:27-31

Masada K, Nagayama T, Hosokawa A, Yoshida M, Suzuki-Kusaba M, Hisa H, Kimura T, Satoh S (1999) Effects of adrenomedullin and PAMP on adrenal catecholamine release in dogs. Am J Physiol 276:R1118-R1124

Mazzocchi G, Albertin G, Andreis PG, Neri G, Malendowicz LK, Champion HC, Bahcelioglu M, Kadowitz PJ, Nussdorfer GG (1999) Distribution, functional role, and signaling mechanism of adrenomedullin receptors in the rat adrenal gland. Peptides 20:1479-1487

McKenzie S, Marley PD (2002) Caffeine stimulates Ca(2+) entry through store-operated channels to activate tyrosine hydroxylase in bovine chromaffin cells. Eur J Neurosci 15:1485-1492

Miao Z, Luker KE, Summers BC, Berahovich R, Bhojani MS, Rehemtulla A, Kleer CG, Essner JJ, Nasevicius A, Luker GD, Howard MC, Schall TJ (2007) CXCR7 (RDC1) promotes breast and lung tumor growth in vivo and is expressed on tumor- 
associated vasculature. Proc Natl Acad Sci USA 104:1573515740

Moretti C, Mammi C, Frajese GV, Mariani S, Gnessi L, Arizzi M, Wannenes F, Frajese G (2006) PACAP and type I PACAP receptors in human prostate cancer tissue. Ann N Y Acad Sci 1070:440-449

Nakamura M, Han B, Nunobiki O, Kakudo K (2006) Adrenomedullin: a tumor progression factor via angiogenic control. Curr Cancer Drug Targets 6:635-643

Nielsen HS, Hannibal J, Fahrenkrug J (1998) Prenatal expression of pituitary adenylate cyclase activating polypeptide (PACAP) in autonomic and sensory ganglia and spinal cord of rat embryos. Ann N Y Acad Sci 865:533-536

O'Hare MM, Schwartz TW (1989) Expression and precursor processing of neuropeptide $\mathrm{Y}$ in human pheochromocytoma and neuroblastoma tumors. Cancer Res 49:7010-7014

Payet MD, Bilodeau L, Breault L, Fournier A, Yon L, Vaudry H, Gallo-Payet N (2003) PAC1 receptor activation by PACAP-38 mediates $\mathrm{Ca}^{2+}$ release from a cAMP-dependent pool in human fetal adrenal gland chromaffin cells. J Biol Chem 278:16631670

Pons J, Kitlinska J, Ji H, Lee EW, Zukowska Z (2003) Mitogenic actions of neuropeptide $\mathrm{Y}$ in vascular smooth muscle cells: synergetic interactions with the beta-adrenergic system. Can J Physiol Pharmacol 81:177-185

Renshaw D, Thomson LM, Michael GJ, Carroll M, Kapas S, Hinson JP (2000) Adrenomedullin receptor is found exclusively in noradrenaline-secreting cells of the rat adrenal medulla. J Neurochem 74:1766-1772

Reubi JC, Laderach U, Waser B, Gebbers JO, Robberecht P, Laissue JA (2000) Vasoactive intestinal peptide/pituitary adenylate cyclase-activating peptide receptor subtypes in human tumors and their tissues of origin. Cancer Res 60:3105-3112

Rose PM, Lynch JS, Frazier ST, Fisher SM, Chung W, Battaglino P, Fathi Z, Leibel R, Fernandes P (1997) Molecular genetic analysis of a human neuropeptide $\mathrm{Y}$ receptor. The human homolog of the murine "Y5" receptor may be a pseudogene. J Biol Chem 272:3622-3627

Ruscica M, Dozio E, Motta M, Magni P (2007) Role of neuropeptide $\mathrm{Y}$ and its receptors in the progression of endocrine-related cancer. Peptides 28:426-434

Shimoda K, Shen GH, Pfeiffer RF, McComb RD, Yang HY (1993) Antiserum against neuropeptide $\mathrm{Y}$ enhances the nicotine-mediated release of catecholamines from cultured rat adrenal chromaffin cells. Neurochem Int 23:71-77

Shimosawa T, Fujita T (2005) Adrenomedullin and its related peptide. Endocr J 52:1-10

Spinazzi R, Andreis PG, Nussdorfer GG (2005) Neuropeptide-Y and Y-receptors in the autocrine-paracrine regulation of adrenal gland under physiological and pathophysiological conditions (Review). Int J Mol Med 15:3-13

Takahashi K, Totsune K, Murakami O, Sone M, Itoi K, Miura Y, Mouri T (1993) Pituitary adenylate cyclase activating polypeptide (PACAP)-like immunoreactivity in pheochromocytomas. Peptides 14:365-369

Tatemoto K, Carlquist M, Mutt V (1982) Neuropeptide Y-a novel brain peptide with structural similarities to peptide YY and pancreatic polypeptide. Nature 296:659-660

Thouënnon E, Elkahloun AG, Guillemot J, Gimenez-Roqueplo AP, Bertherat J, Pierre A, Ghzili H, Grumolato L, Muresan M, Klein M, Lefebvre H, Ouafik L, Vaudry H, Plouin PF, Yon L, Anouar $Y$ (2007) Identification of potential gene markers and insights into the pathophysiology of pheochromocytoma malignancy. J Clin Endocrinol Metab 92:4865-4872

Thouënnon E, Pierre A, Tanguy Y, Guillemot J, Manecka DL, Guerin M, Ouafik L, Muresan M, Klein M, Bertherat J, Lefebvre H, Plouin PF, Yon L, Anouar Y (2010) Expression of trophic amidated peptides and their receptors in benign and malignant pheochromocytomas: high expression of adrenomedullin RDC1 receptor and implication in tumoral cell survival. Endocr Relat Cancer 17:637-651

Tonshoff C, Hemmick L, Evinger MJ (1997) Pituitary adenylate cyclase activating polypeptide (PACAP) regulates expression of catecholamine biosynthetic enzyme genes in bovine adrenal chromaffin cells. J Mol Neurosci 9:127-140

Uzan B, Villemin A, Garel JM, Cressent M (2008) Adrenomedullin is anti-apoptotic in osteoblasts through CGRP1 receptors and MEK-ERK pathway. J Cell Physiol 215:122-128

Vaudry D, Falluel-Morel A, Bourgault S, Basille M, Burel D, Wurtz O, Fournier A, Chow BK, Hashimoto H, Galas L, Vaudry H (2009) Pituitary adenylate cyclase-activating polypeptide and its receptors: 20 years after the discovery. Pharmacol Rev 61: 283-357

Wang J, Shiozawa Y, Wang J, Wang Y, Jung Y, Pienta KJ, Mehra R, Loberg R, Taichman RS (2008) The role of CXCR7/RDC1 as a chemokine receptor for CXCL12/SDF-1 in prostate cancer. J Biol Chem 283:4283-4294

Yon L, Breault L, Contesse V, Bellancourt G, Delarue C, Fournier A, Lehoux JG, Vaudry H, Gallo-Payet N (1998) Localization, characterization, and second messenger coupling of pituitary adenylate cyclase-activating polypeptide receptors in the fetal human adrenal gland during the second trimester of gestation. J Clin Endocrinol Metab 83:1299-1305

Zudaire E, Martinez A, Cuttitta F (2003) Adrenomedullin and cancer. Regul Pept 112:175-183

Zukowska Z, Pons J, Lee EW, Li L (2003) Neuropeptide Y: a new mediator linking sympathetic nerves, blood vessels and immune system? Can J Physiol Pharmacol 81:89-94 